\title{
How CSR Activities Affect Student Attitudinal and Behavioral Loyalty in the Lebanese Educational Sector?
}

Rania B. Mostafa, College of Business, Al Ain University, UAE \& Damanhour University, Egypt

Leila Hamieh, Beirut Arab University, Lebanon

\begin{abstract}
The success of any organization is settled on its ability of initiating, sustaining, and retaining a good customer relationship based on loyalty. Corporate social responsibility (CSR) turned out to be considered as an efficient marketing tool. However, the impact of CSR on loyalty is still uncultivated. The paper investigates the influence of CSR activities on both loyalty constructs: attitudinal loyalty as well as behavioral loyalty. Based on a sample of 203 Lebanese students, results revealed a considerable effect of ethical, legal, and philanthropy social responsibility on both attitudinal and behavioral loyalty. Conversely, the effect of economic responsibility on attitudinal and behavioral loyalty was insignificant.
\end{abstract}

\section{KEYWORDS}

Attitudinal Loyalty, Behavioral Loyalty, Corporate Social Responsibility, Economic Responsibility, Ethical and Legal Responsibility, Philanthropy Responsibility

\section{INTRODUCTION}

For many decades, studies focused on defining and highlighting the importance of corporate social responsibility (CSR) (Choi et al., 2017; Luu, 2017). For marketers, CSR is valued as an important marketing tool that grants a useful interaction and valuable connection between the service providers and their customers (Singh et al., 2008) due to its effect on consumer behavior. Other scholars highlighted the role and importance of CSR in building or enhancing the brand (Kang \& Namkung, 2017), firm performance (Wang et al., 2015), and brand equity with the aim of supporting the firm's positive image in retaining existing customers, in addition to trying to attract new ones (Kang \& Namkung, 2017).

Researchers (e.g., Fatma \& Rahman, 2016; Nyadzayo \& Khajehzadeh, 2016) explored the correlation between CSR and loyalty. Werther and Chandler (2005) declared that corporate social responsibility has a straight and direct influence on customer loyalty. Whereby, Salmons et al. (2005) did not conclude a direct association between social responsibility and loyalty. Furthermore, CSR has a variety of measurements, thus it is fundamental to evaluate each component of CSR to assess the way it will be perceived by customers (Maignan \& Ferrell, 2001). However, Aljarah and Ibrahim

DOI: 10.4018/IJCRMM.290416

This article published as an Open Access article distributed under the terms of the Creative Commons Attribution License (http://creativecommons.org/licenses/by/4.0/) which permits unrestricted use, distribution, and production in any medium, provided the author of the original work and original publication source are properly credited. 
(2020) request scholars to examine the effect of each of the dimensions of CSR (economic, ethical, legal, and social) on attitudinal and behavioral loyalty.

Recent studies (Farrukh et al., 2019; Waheed \& Yang, 2019) propose that researchers must advance their studies and investigations in order to validate the findings and significance of CSR initiatives within different angles. The value of the current study could also be cherished based on the various requests made by current research. For example, Enzgizek and Yasin (2017) highlighted the importance of exploring the impact of CSR on customer attitudinal and behavioral outcomes, notably in the service sector. Thus, our study addresses this gap in the CSR literature with respect to the buying behavior of consumers and attitudes toward the organization.

In addition, scarce research focused on CSR initiatives in the developing countries, particularly for the middle east countries. Specifically, CSR accomplishment in Lebanon is still very narrow and adopted by few organizations, in specific fields. Thus, there is a significant lack of consciousness about CSR in Lebanese corporations and this fact will negatively affects company's competitiveness, profitability, and sustainable growth (CSR Lebanon, 2018). Especially that Lebanon and Lebanese communities are calling for a safer, cleaner, and healthier environment to live in. Firms are no longer allowed to operate as isolated entities without taking into account the effects and consequences of their actions on the society and environment in which they operate. Thus, firms are invited to acknowledge their responsibility toward all their stakeholders by supporting the welfare of all the society, and not just focusing on profit maximization to satisfy their shareholders' needs (Hejase et al., 2012).

Although, CSR is encouraged by multinational companies, it can be also important for universities, since they are the greatest provider for the creation and development of future entrepreneurs, businesses leaders, and managers (Wright, 2010). Furthermore, student's loyalty is an important factor for entities like universities to ensure a sustainable development (Kilburn, Kilburn, \& Davis, 2016). For example, by retaining existing students, universities will be able to reduce their cots much more than acquiring new students (Hennig-Thurau, Gwinner, \& Gremler, 2002; Mostafa, 2019). Pham, Williamson, and Berry (2018) ensured that loyal students are characterized by their high commitment through their continual comments and suggestions that will improve the quality of the educational program. Hence, they will be engaged telling their relatives and friends about their positive experiences and will motivate others to enroll and register in this particular university (Helgesen \& Nesset, 2007).

Accordingly, this study is conducted in Lebanese higher educational sector since Lebanon is facing different problems from fierce competition to financial problems. Thus, it is fundamental to assess the impact of CSR initiatives on customer related outcome such as customer loyalty.

The question raised in the present paper is: «What is the impact of CSR initiatives on customer loyalty »? More specifically, a further question is posed: what the effect of each of CSR dimensions (legal and ethical responsibilities, economic responsibilities, and philanthropy responsibilities) on attitudinal and behavioral loyalty is.

Drawing on these considerations, the present research extends the existing knowledge of the effect of CSR on maintaining customer loyalty, and thus grant positive discernment by clarifying for marketing professionals and universities managers on how CSR could be effective.

\section{THEORETICAL BACKGROUND}

\section{Customer Loyalty}

The notion of customer loyalty is very crucial in establishing effective and successful businesses (Oliver, 1999; Chaudhuri \& Holbrook, 2001; Lewis \& Soureli, 2006; Kotler \& Armstrong, 2008). Previous studies highlighted the factors that impact customer loyalty like customer trust (Sirdeshmukh et al., 2002), customer commitment (Evanschitzky et al., 2006), brand love (Correia Loureiro \& Kaufmann, 2012), service quality, brand awareness, and brand association (Nikabadi et al., 2015), and customer satisfaction (Fatma et al., 2018). A review of literature on customer loyalty established 
by Kumara et al., (2018) depicted the most significant antecedent of customer loyalty including perceived value, customer satisfaction, service quality, corporate image, trust, loyalty programmers, and switching costs. Whereby, the direct and indirect relationship between these antecedents will strengthen their influence on customer loyalty (Kumara et al., 2018). Additionally, previous research indicates the role of customer loyalty as an instrument that indicates the customer attachment to the brand (Aaker, 1991). Scholars ensured that the brand achievement for a long period of time is linked to the increase in the number of consumers who turned out to be frequent buyers and not the number of consumers who buy for just one time (Jacoby \& Chestnut, 1978). Especially, that the charge paid by the company to obtain a new customer is expensive compared to the benefit and prosperity gained from retaining a previous customer (Chiou \& Droge, 2006). Loyalty is a key factor for long run profitability (Bolton et al., 2004; Chiou \& Droge, 2006) since earnings will rise through customer retention on the long run.

Previous studies have operationalized loyalty under two elements; attitudinal loyalty and behavioral loyalty (Jacoby \& Chestnut, 1978; Oliver, 1999). Measuring loyalty based on behavioral dimensions (e.g., repeat purchase and exclusive purchase), and attitudinal dimension (e.g., positive word -of- mouth and intention to buy), has been adopted in different research paper, particularly in Chaudhuri and Holbrook (2001) study. Attitudinal loyalty is considered as the "personal attitude" since that the different emotions will structure the customer's loyalty toward a product or service, while behavioral loyalty reflects consumer's repeated purchasing behavior (Zeithaml et al., 1996).

\subsection{Behavioral Loyalty}

Behavioral loyalty refers to the repeated purchase of the same trade name and product over a certain period of time (Chaudhuri \& Holbrook, 2001). Thus, researchers considered that the actual purchase as the initial measurement for loyalty (Guadagni \& Little, 1983; Tellis, 1988). Behavioral loyalty is associated with different consequences such as repurchase intentions and switching intentions (Worthington et al., 2010) as well as purchase frequency (Broyles, 2009). However, scholars ensured that loyalty construct is not clearly understood without taking into consideration a new variable that measures customer's attitude toward the brand (Backman \& Crompton, 1991; Dick \& Basu, 1994), because repeated purchase may result from personal, psychological, situational, or marketing factors (Oliver, 1999), just like inertia of purchase for saving time and money (Bennett \& Rundle-Thiele, 2002), substitute shortage (Backman \& Crompton, 1991; Oppermann, 2000) as well as product and service accessibility (Newman \& Werbel, 1973).

\subsection{Attitudinal Loyalty}

The attitudinal dimension of loyalty is defined as the consumer overall preferences and intentions (Jacoby \& Kyner, 1973). Dick and Basu (1994) focused on attitudinal loyalty as individual robust attitudes toward the seller/brand, in which this emotional long-lasting relationship is linked to a sense of loyalty, allegiance, and engagement (Bowen \& Chen, 2001). Attitudinal loyalty refers to a strong repurchase intention, positive WOM, ability to afford a certain price, product preferences and not substituting their product or service toward competitors' products (Anderson \& Srinivasan, 2003; Zeithaml, et al., 1996).

\subsection{The Educational Sector in Lebanon}

Lebanon was among the first countries of the MENA area to launch a university in 1866; consequently, Lebanon's higher education sector has been considered a leader in the region (Fares, 2020). The Lebanese educational sector offered Lebanese and international students an excellent service with more than 40 private universities and one public university (Aljardali, et al., 2020). Higher education in Lebanon returns back to 1866 with the establishment of the first university American University of Beirut, that was known in the name of the Syrian Evangelical College, then it was followed by Saint Joseph University in 1875, and then in 1947 the Lebanese American university, to be followed 
by Beirut Arab University in 1960 (Khawaja et al., 2020). Lebanese universities offer numerous majors of studies such as business administration, law with a percentage of $26.2 \%$ and literature and arts representing around 19.3\% (Khawaja et al., 2020), with a total of 79360 student enrolled in Lebanese universities (Central Administration of Statistics, and Center for educational research and development, 2018).

As said by Saad Hariri (the Lebanese Prime Minister), the higher education sector is a crucial factor that derive the magical mix that characterize Lebanon and represent a unique a source of initiative, creativity, excellence, and success in the middle east and the world (Alami, 2019). Moreover, the private high education sector is extremely significant and vital for the Lebanese society (Aljardali, et al., 2020). However, the country is witnessing a fatal financial and economic crisis as well as the COVID-19 pandemic that endured hardly the educational sector with its various components, particularly the higher education sector (Abdul-Reda Abourjeili, \& Harb, 2020). These crises have endangered both students and universities, in which students are unable to pay for their studies, thus, threatening the survival of the country's universities (Dhabi, 2020). In other terms, universities are reconsidering their survival strategies by highlighting the importance of CSR to create a competitive advantage (Khawaja et al., 2020).

\subsection{Loyalty in The Educational Sector}

Academics highlighted the worth of student loyalty in the educational sector (Choudhury, 2015; Austin $\&$ Pervaiz, 2017). The conception of student loyalty engages both attitudinal loyalty and behavioral loyalty (Vianden \& Barlow, 2014). In term of behavioral loyalty, student will have the intention to pursue his current and further education in the same organization (Mohamad \& Awang, 2009). However, attitudinal loyalty is reflected in assisting other students in the same university, spreading a positive word of mouth, and being engaged in institutional donation (Hennig-Thurau et al., 2001).

The Lebanese higher education environment has been widely affected by the fierce competition, particularly with the development of new private universities and many Lebanese colleges shifting to full universities (Easa \& Bazzi, 2020). Furthermore, the high number of Lebanese universities that support the American credit system are experiencing an increase in student's disloyalty (Easa \& Bazzi, 2020), thus they are trying to adopt new strategies and policies (Abouchedid \& Nasser, 2002) such as providing a various range of academic majors aiming to overcome the situation (Easa \& Bazzi, 2020).

\section{Corporate Social Responsibility}

According to Carroll (1979), CSR is a multidimensional construct. Economic responsibilities constitute the first element of the pyramid in which all other responsibilities are based on. It refers to the organization goal in realizing profit, as well as increasing the return per share and creating an effective competitive advantage and a particular post and attitude in the market (Carroll, 1991). However, the legal and ethical responsibility refers to the organization responsibility toward acceptable and unacceptable behavior in term of legal requirement as well as the participation in activities that respect the social morals and ethical norms (Carroll, 1991). Philanthropic responsibilities are judged as an authoritarian procedure that enhances and support the common good and the wellbeing and the welfare of others (McWilliams \& Siegel, 2001). Philanthropic responsibility is achieved through voluntarily donation for tangible and intangible products and services (Carrroll, 1991) such as cash, expertise, employee time and many others (Cho, et al., 2017).

The conception of corporate social responsibility has been a major issue over the past years (Shin et al., 2014). Shabbir, et al. (2018) developed a framework to explore the relationship between CSR and corporate performance by highlighting the role of customer loyalty as a proxy of performance. The framework explained the role of CSR grounded on the stakeholder theory. Findings of the study showed the significant influence of CSR on customer loyalty with the mediating role of brand image. Howes et al. (2017) explored the role of CSR in guaranteeing the firm's survival in a fierce competitive environment through stimulating sustainability in business operations. 
Accordingly, Khawaja et al. (2021) state that CSR is a "requirement" in the university sector, since universities are offering a long-lasting service for their students with different parties like instructors, parents, industries, government, alumni, and professional institutes (Moogan, 2011). Furthermore, a recent finding revealed that economic, ethical, and philanthropic CSR are crucial in enhancing brand attitude and service quality (Lee et al., 2020).

\section{CSR and Loyalty}

Brand loyalty is defined as the fundamental aspect that reveals the brand's value (Aaker, 1991). Studies revealed that customer is mainly the most limited resource, as well as that customer devotion to the brand has a direct influence on the organization's return and expansion (Zeithaml et al., 1996; O'Cass $\&$ Sok, 2015). For instance, many studies affirmed the significant correlation between CSR and loyalty (Fatma et al., 2016; Nyadzayo \& Khajehzadeh, 2016). For example, some studies underlined the importance of CSR in supporting the organization financial and improving brand loyalty (Pivato et al., 2008). Raza et al. (2020) affirmed that the connection between CSR and customer loyalty is justified based on the theory of social exchange (Raza et al., 2020). Blau (1964) declared that company's involvement in socially responsible initiatives and behaviors creates a phenomenon of generalized reciprocity. In the same manner, Eisingerich, et al. (2011) declared that based on the principle of reciprocity CSR activities may be adopted by firms to impact consumer behavior. Moreover, Brown and Dacin (1977) recognized the fact that CSR initiatives will affect consumer behavioral outcomes via several pathways, either directly or indirectly. In the same vein, Bhattacharya and Sen (2004) affirmed that a firm's CSR initiatives, associated with effective and robust corporate abilities, will lead to positive attributions and customer-firm identification, hence generating favorable behaviors.

On the other hand, Tajfel and Turner (1986) explained the association between CSR activities and customer loyalty according to the social identity theory. Hence, when consumer feel identified with the firm, while believing that it is adopting the best CSR initiatives, in that case the value of the firm will be higher with an important level of commitment and more positive attitudes toward this firm (Miles, 2012). Practically, different scholars adopted this theory to explore the positive influence of customer perceptions of CSR on consumers' loyalty such (e.g., Lu et al., 2017). Recent studies has shown that CSR has the power to influence consumers' loyalty in various industries like hypermarkets (Cuesta-Valiño et al., 2019; Servera-Francés, \& Piqueras-Tomás, 2019), health insurance companies in Spain (Iglesias et al., 2018), as well as the banking industry in Pakistan (Raza et al., 2020).

\subsection{CSR and behavioral Loyalty}

Basically, companies must assess the impact of CSR activities on customers' behavioral loyalty since it will impact their profitability (Ailawadi et al., 2014). However, research exploring CSR's correlation to behavioral loyalty is scarce and findings have shown a fragile relationship (Ailawadi et al., 2014).

Based on both theories, social identity and company identification, literature proposes that customers aim to enhance companies that have a positive and distinctive identity that is involved in CSR activities (Ailawadi et al., 2014; Bhattacharya \& Sen, 2003). Accordingly, customers will reward these types of companies with a superior level of loyalty, reflected by increasing the firm's financial value (Ailawadi et al., 2014). Furthermore, based on the automaticity effect established by social scientists, behaviors may be inspired by a certain stimulus in the environment without a conscious thought procedure (Bargh et al., 1996). Therefore, CSR activities might be considered as this stimulus that will induce consumers to shop or avoid the store (Bitner, 1992).

Previously, Martinez and Bosque (2013) empirically found that indirect relationship between perceived CSR and customer's loyalty in a hotel industry in Spain through the mediating role of customer satisfaction and trust. In a recent study, Liu et al. (2019) investigated how CSR can influence customer behavioral loyalty in the hotel service. Accordingly, perception of CSR will guarantee a positive content to brand image (Liu et al., 2019), since customer consider that whenever brands are engaged in CSR activities, the more they are likely to provide honest information about the product 
and good quality (He \& Lai, 2014). Furthermore, brand image plays a vital role in earning customer's trust (Liu et al., 2019), hereby perceived CSR will stimulate consumer's trust through brand image (Liu et al., 2019). Hence, findings of the study affirmed the impact of CSR on customer behavioral loyalty via the mediating role of brand image and customer trust in the hotel context in China.

Furthermore, previous studies (He \& Lai, 2014; Kim \& Ham, 2016) investigated that CSR activity dimensions will improve brand loyalty by strengthening the positive brand image, thus, the customer behavioral loyalty. However, the empirical results revealed by the study of Mandhachitara and Poolthong (2011) ensured that repurchase intention, the core of behavioral loyalty is affected by CSR.

Therefore, the following hypotheses are proposed:

H.1.a. Economical responsibility has a positive impact on behavioral loyalty.

H.1.b. Ethical - Legal responsibility has a positive impact on behavioral loyalty.

H.1.c. Philanthropy responsibility has a positive impact on behavioral loyalty.

\subsection{CSR and attitudinal Loyalty}

Extensive body of research has evaluated the positive correlation between corporate social responsibility and attitudinal loyalty (Lacey et al., 2015; Walsh \& Bartikowski, 2013; Lichtenstein et al., 2004). Scholars argued that CSR actions encourage customer attitude toward the brand and the organization (Folks \& Kamins, 1999; Bhattacharya \& Sen, 2003; Lichtenstein et al., 2004). Accordingly, attitude will impact certain consumer behavior like spreading positive word of mouth (Marin et al. 2009; Brown \& Dacin 1997). Vlachos et al. (2009) argued that firms with adequate and good corporate social responsibility initiatives are promptly compensated by positive word of mouth (WOM) referral.

Mandhachitara and Poolthong (2011) explored a model of customer loyalty and corporate social responsibility that clarified the correlation between CSR, perceived service quality, attitudinal loyalty, and repeat patronage intention. For this reason, they addressed a questionnaire to retail banking customers residing in Bangkok to verify the correlation between these variables. Their empirical findings revealed a direct and positive correlation between CSR activities and attitudinal loyalty ensuring that customer perception of CSR activities will impact consumer attitudes toward the organization and its offerings.

In their empirical study, Servera-Francés, and Piqueras-Tomás (2019) aimed to explore how company's involvement in CSR activities will increase consumer value, satisfaction. and attitudinal loyalty. Results revealed approved the hypotheses proposed, thus CSR activities increase the value and trust perceived by customers. In the same manner, trust will support consumer commitment toward the organization while upgrading and boosting the perceived value. Finally, commitment will have a positive and significant impact on customer attitudinal loyalty. Han, Yu, Lee, and Kim (2019) highlighted the importance of ethical practices and the company's performance in generating a strong attitudinal loyalty. Accordingly, the present paper formulates the following hypotheses:

H.2.a. Economical responsibility has a positive impact on attitudinal loyalty.

H.2.b. Ethical - Legal responsibility has a positive impact on attitudinal loyalty.

H.2.c. Philanthropy responsibility has a positive impact on attitudinal loyalty.

\section{CONCEPTUAL FRAMEWORK}

The present study aims to explore the direct relationship between customer loyalty and corporate social responsibility and to confirm this relation in the Lebanese educational sector. Hence, the conceptual framework, represented in Figure 1 depicts the effect of the three dimensions of CSR 
activities (economic responsibility, ethical-legal responsibility, and philanthropy responsibility) on the two dimensions of customer loyalty (attitudinal loyalty and behavioral loyalty).

Figure 1. Conceptual framework

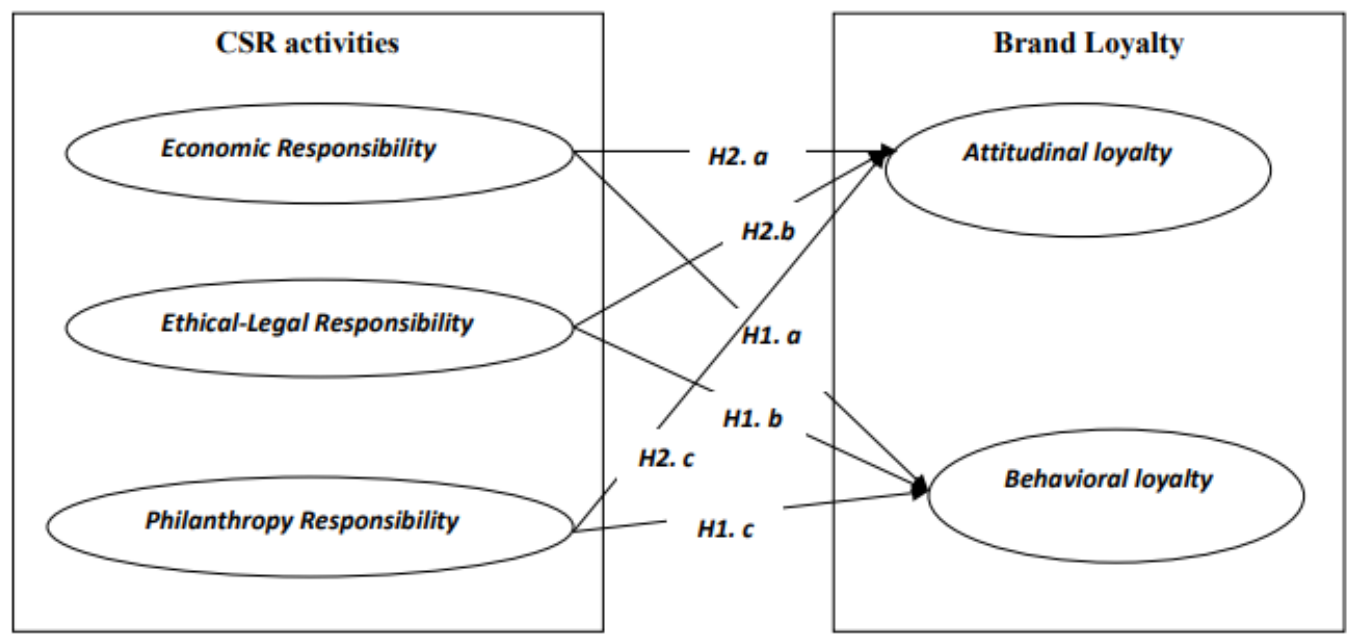

\section{METHODOLOGY}

\section{Sample and Data Collection}

In order to collect the accurate information, while minimizing error, quantitative research approach is conducted. Data were collected from students of three universities in Lebanon through an online questionnaire. The sampling technique was a convenient sampling, due to the convenient source of data from different Lebanese area.

Geared toward assessing the respondents' knowledge about the variables of this study, scales from previous literature were used. A pre-test of 10 students was conducted to indicate the changes needed, before launching the final online questionnaire for the potential response.

The study collected 205 questionnaires. However, two questionnaires were excluded because they were incomplete. The final sample of this study consisted of 203 respondents who completed the questionnaire. Table 1 shows the demographic profile for the respondents.

Among the two hundred and three valid questionnaires we received, $71.8 \%$ of respondents were females and $28.2 \%$ males. Moreover, majority of the respondents $(82.8 \%)$ was between the age 18 and 25 with a bachelor's degree (71\%). Most of the respondents $(48.2 \%)$ get monthly income less than 750,000 Lebanese Pounds. However, most of the respondents (48.5\%) are students at Saint Joseph University.

\section{Measures}

The online questionnaire was divided into two parts. The first to assess the demographic information related to the sample (age, income, educational level, gender, and university). The second part of the questionnaire includes the five research variables. 
Table 1. Demographic profile

\begin{tabular}{|l|l|l|l|}
\hline No & Demographic Factor & Characteristics & Percent \\
\hline 1 & Gender & Male & 28.2 \\
& & Female & 71.8 \\
\hline 2 & Age & $18-25$ & 82.8 \\
& & $25-35$ & 16.3 \\
& & $35-45$ & 0.9 \\
\hline 3 & Educational level & +46 & 71 \\
& & Bachelor & 24 \\
\hline 4 & & Master & 5 \\
\hline & Income & PHD & 48.2 \\
& & Less 750000 LBP & 21.8 \\
& & $750000-1500000$ LBP & 15.2 \\
& & $1500000-2250000$ LBP & 14.8 \\
\hline 5 & University & $2250000-3000000$ LBP & 26.2 \\
& & AUB & 25.3 \\
& & LAU & 48.5 \\
\hline
\end{tabular}

The research variables are assessed on multiple items on a seven-point Likert scale. Corporate social responsibility is a multidimensional construct and includes three dimensions; economic, political-legal, and philanthropic responsibilities. Those three dimensions were measured using Salmon et al. (2005) scale. Attitudinal loyalty as well as behavioral loyalty are measured by three and five items, respectively, developed by Choi et al. (2017).

\section{Data Analysis and Results}

Cronbach's alpha test was used to ensure reliability of the questionnaire items. Accordingly, the measurement model's constructs are characterized by a good reliability in which alpha range between 0.62 and 0.95 (Table 2).

Table 2. Descriptive Statistics and correlation

\begin{tabular}{|l|l|l|l|l|l|l|l|l|}
\hline & & \multicolumn{5}{|l|}{ Correlation } & \multicolumn{3}{l|}{} \\
\hline & $\mathbf{M}$ & SD & Cronbach & $\mathbf{1}$ & $\mathbf{2}$ & $\mathbf{3}$ & $\mathbf{4}$ & $\mathbf{5}$ \\
\hline $\begin{array}{l}\text { Attitudinal } \\
\text { loyalty }\end{array}$ & 5.40 & 1.69 & 0.90 & 1 & & & \\
\hline $\begin{array}{l}\text { Behavioral } \\
\text { loyalty }\end{array}$ & 5.19 & 1.76 & 0.95 & 0.07 & 1 & & & \\
\hline Economic & 5.44 & 1.18 & 0.62 & $.35^{* *}$ & $.16^{*}$ & 1 & & \\
\hline Ethical-legal & 5.34 & 1.28 & 0.82 & $.65^{* *}$ & 0.13 & $.49^{* *}$ & 1 & 1 \\
\hline Philanthropy & 5.40 & 1.26 & 0.86 & $.62^{* *}$ & 0.05 & $.42^{* *}$ & $.66^{* *}$ & 1 \\
\hline
\end{tabular}

Notes: ${ }^{* *} p<0.01 ;{ }^{*} p<0.05$ 
To test the hypothesis an ordinary least square applied was conducted, using the SPSS statistics. Table 3 shows the structural model estimates.

Table 3. Structural model estimates

\begin{tabular}{|l|l|l|l|l|l|l|}
\hline & \multicolumn{2}{l}{ Attitudinal loyalty } & \multicolumn{2}{l|}{ Behavioral loyalty } \\
\hline Constructs & Beta & T-test & P-value & Beta & T-test & P-value \\
\hline Economic responsibility & -0.003 & -0.04 & 0.97 & 0.008 & 0.09 & 0.93 \\
\hline Ethical -legal responsibility & 0.57 & 6.08 & $0.00^{* * * *}$ & 0.69 & 7.47 & $0.00^{* * *}$ \\
\hline Philanthropy responsibility & 0.45 & 4.83 & $0.00^{* * * *}$ & 0.43 & 4.70 & $0.00^{* * *}$ \\
\hline
\end{tabular}

Notes: ${ }^{* * *} p<0.001$.

Results show that all hypotheses are supported except for H1a and H2a. Results indicate that ethical and legal CSR activities have a positive and significant influence on both attitudinal $(\beta=0.57$, $\mathrm{p}<0.005)$ and behavioral loyalty $(\beta=0.69 ; \mathrm{p}<0.005)$, hence supporting $\mathrm{H} 1 \mathrm{~b}$ and $\mathrm{H} 2 \mathrm{~b}$.

Moreover, the influence of philanthropy CSR activities on attitudinal $(\beta=0.45, \mathrm{p}<0.005)$ and behavioral loyalty $(\beta=0.43, \mathrm{p}<0.005)$ are significant and positive. Consequently, H1c and $\mathrm{H} 2 \mathrm{c}$ are supported. However, the effect of economic CSR activities on attitudinal $(\beta=-0.003, p>0.005)$ and behavioral loyalty $(\beta=0.008, \mathrm{p}>0.005)$ are insignificant. Therefore, H1a and $\mathrm{H} 2 \mathrm{~b}$ are not supported. Table 4 provides summary of the results of hypotheses testing.

\section{Table 4. Summarized results of hypotheses testing}

\begin{tabular}{|l|l|l|}
\hline Hypothesis & Relationship & Remarks \\
\hline H1a & Economic-behavioral loyalty & Not supported \\
\hline H1b & Ethical Legal- behavioral loyalty & Supported \\
\hline H1c & Philanthropy-behavioral loyalty & supported \\
\hline H2a & Economic-attitudinal loyalty & not supported \\
\hline H2b & Ethical Legal- attitudinal loyalty & Supported \\
\hline H2c & Philanthropy-attitudinal loyalty & Supported \\
\hline
\end{tabular}

\section{DISCUSSION AND IMPLICATIONS}

The present research examined consumer responses to the three dimensions of CSR (economic, ethicallegal, and philanthropy dimensions) and provides some implications for marketer and practitioners. Particularly, the main purpose of our study was to explore whether the different CSR activities, in terms of economical, legal, ethical and philanthropy activities will have an influence on the attitudinal and behavioral loyalty in the Lebanese higher education sector.

The findings reported in our paper extend the literature on the influence of CSR dimensions on behavioral and attitudinal loyalty. Therefore, when evaluating company's ethical, legal and philanthropic activities, CSR will have a significant impact on their attitudinal and behavioral loyalty to the institution. However, when evaluating company's economic activities, CSR does not impact student's loyalty. In other terms, all CSR dimensions have positive influence on customer loyalty, 
except for economic responsibility, in which making profit to shareholders cannot drive customer loyalty. This finding contrast with Onalor and Rotchanakitumnuai (2010) results in which customer loyalty has been positively affected by economic responsibility, legal-ethical responsibility, and philanthropy responsibility. The reason behind this dissimilarity may be caused by the difference in the conceptualization of the economic responsibility since Onalor and Rotchanakitumnuai (2010) considered the economy component as the customer perception about price fairness.

Furthermore, the present findings also shed light on the direct association between CSR different components and customer attitudinal and behavioral loyalty in the Lebanese Educational sector. The existence of the path between CSR and loyalty has been empirically supported in this study. The findings coincide with the findings of other scholars like Kim et al. (2016) who found that consumer's perceptions of CSR activities in the hospitality sector will affect consumer's attitudinal and behavioral reaction toward restaurants social activities.

Hence, this study shows that consumer's attitudinal and behavioral loyalty are positively affected by CSR activities. However, Salmones, Crespo, and Bosque (2005) failed to show any direct correspondence between these two variables (i.e., CSR and loyalty) (Gürlek et al., 2017), considering that the power of the service valuation is the most important and effective antecedent for customer loyalty. This difference between our findings and Salmones, Crespo, and Bosque (2005) can be explained by the fact that Salmones, Crespo, and Bosque (2005) conducted their analysis in a different domain, the telecommunication service rather than the education service that is characterized by a high level and continuous level of contact between the university and the student. Besides, the culture factor can be the reason behind this divergence since Lebanese mentality is different from other people with different culture.

\section{Theoretical Implications}

This paper provides significant theoretical contributions represented by introducing a conceptual design which incorporate the dimensions of corporate social responsibility, along with integrating not only attitudinal loyalty but also the behavioral loyalty constructs. Moreover, results revealed the importance of legal, ethical, and philanthropy responsibilities in influencing consumer intentional behavior (attitudinal loyalty), as well as their actual behavior response (behavioral loyalty).

The present study shows the way to a better understanding of the correlation between CSR and loyalty. While in previous studies the conceptualization of CSR was broad, the present study tested the three types of CSR that might impact brand loyalty, by referring to the model of Carroll and linking it to brand loyalty. Moreover, the study was able to assess the influence of CSR on each dimension of brand loyalty constructs in terms of behavioral loyalty and attitudinal loyalty. Besides, the paper provides an empirical study in the Lebanese higher education since the developed model and the proposed hypotheses were not empirically tested previously in the Lebanese private universities sector. Thus, universities are reconsidering their survival strategies by stimulating the role of CSR as a competitive advantage that can positively affect customer loyalty.

\section{Managerial Implications}

Since technological, environmental, and demographic shifts are redefining the global world, Lebanese universities are required to synchronize competitive strategies in order to enhance and maintain a high customer loyalty specifically that the competition is severe between Lebanese universities in the private sector. As per the current study, due to the direct significant correlation among CSR activities and loyalty constructs, marketers must revise their marketing mix strategies by highlighting the power of CSR initiatives in maintaining a strong customer relationship over a long-term period, hence contributing to the firm success and realizing an increase in its financial performance. Therefore, the present study is useful for university administrations, professors, and educators, since it grants a better clarification and understanding for student behavior particularly in a developing country such as Lebanon. Accordingly, to motivate Lebanese students to say positive things about their university, 
support and recommend their university, consider it as their first choice, and keep patronizing it in case of deciding for a further study, universities' decision makers should emphasize philanthropic, ethical, and legal responsibilities. Specifically, universities' decision makers should focus on the ethical-legal responsibility by fulfilling its obligations toward its shareholders, suppliers, distributions, and other agents with whom they deal, respecting the norms outlined in the law when execution the university's activities, behaving ethically/honestly with their students, and respecting ethical principles more than the financial aspects. Moreover, universities' decision makers are recommended to recognize and guard natural environment, to actively sponsor and finance social events (such as sport and musical events), to donate portion of its budget to social works supporting the underprivileged, and to boost the well-being of the public.

\section{Limitations and Suggestions for Future Research}

In spite of the fact that this investigation provides some important contributions, few limitations emerged that display opportunities for further research. First, our study was applied in one service sector that is the higher education, thus future research must be explored in other business areas and sectors to ascertain the generalization of these results. Second, data were collected using cross sectional design, accordingly, future research could conduct a longitudinal research design to track the change in customer loyalty following CSR practices. Third, researcher must examine other variables that might interfere in the relationship between CSR dimensions and customer loyalty constructs such as complaint handling, perceived value, and perceived quality and social media engagement. Hence, incorporating these constructs into the model will permit a more comprehensive framework. 


\section{REFERENCES}

Aaker D. (1991). Managing Brand Equity. The Free Press, A Division of Simon and Schuster Inc.

Abdul-Reda Abourjeili, S., \& Harb, S. (2020). The Deteriorated Educational Reality in Lebanon: Towards "Another" Critical Approach, Arab Reform Initiative, Bawader. https://www.arab-reform.net/publication/thedeteriorated-educational-reality-in-lebanon-towards-another-critical-approach/

Abouchedid, K., \& Nasser, R. (2002). Assuring quality service in higher education: Registration and advising attitudes in a private university in Lebanon. Quality Assurance in Education, 10(4), $198-206$. doi: $10.1108 / 09684880210446866$

Ailawadi, K. L., Neslin, S. A., Luan, Y. J., \& Taylor, G. A. (2014). Does retailer CSR enhance behavioral loyalty? A case for benefit segmentation. International Journal of Research in Marketing, 31(2), 156-167. doi:10.1016/j. ijresmar.2013.09.003

Al Jardali, H., Khaddage-Soboh, N., Abbas, M., \& Al Mawed, N. (2020). Performance management systems in Lebanese private higher education institutions: design and implementation challenges. Higher Education, Skills and Work-Based Learning.

Alami, H. (2019). The Future of Higher Education in Lebanon: Between the Public Order and the Transitions of a New Era. Publications of the Modern University of Management and Sciences.

Aljarah, A., \& Ibrahim, B. (2020). The Robustness of Corporate Social Responsibility and Brand Loyalty Relation: A Meta-Analytic Examination. Journal of Promotion Management, 26(7), 1-35. doi:10.1080/10496 491.2020.1746464

Anderson, R. E., \& Srinivasan, S. S. (2003). E-satisfaction and e-loyalty: A contingency framework. Psychology and Marketing, 20(2), 123-138. doi:10.1002/mar.10063

Austin, A. J., \& Pervaiz, S. (2017). The Relation Between 'Student Loyalty' and 'Student Satisfaction: A case of College/Intermediate Students at Forman Christian College. European Scientific Journal, 13(3), $100-117$.

Backman, S. J., \& Crompton, J. L. (1991). The usefulness of selected variables for predicting activity loyalty. Leisure Sciences, 13(3), 205-220. doi:10.1080/01490409109513138

Bargh, J. A., Chen, M., \& Burrows, L. (1996). Automaticity of social behavior: Direct effects of trait construct and stereotype activation on action. Journal of Personality and Social Psychology, 71(2), 230-244. doi:10.1037/00223514.71.2.230 PMID:8765481

Bennett, R., \& Rundle-Thiele, S. (2002). A comparison of attitudinal loyalty measurement approaches. Journal of Brand Management, 9(3), 193-209. doi:10.1057/palgrave.bm.2540069

Berens, G., van Riel, C. B. M., \& van Rekom, J. (2007). The CSR-quality trade-off: When can corporate social responsibility and corporate ability compensate each other? Journal of Business Ethics, 74(3), $233-252$. doi:10.1007/s10551-006-9232-0

Bhattacharya, C. B., \& Sen, S. (2003). Consumer-Company Identification: A Framework for Understanding Consumers' Relationships with Companies. Journal of Marketing, 67(2), 76-88. doi:10.1509/jmkg.67.2.76.18609

Bhattacharya, C. B., \& Sen, S. (2004). Doing better at doing good: When, why, and how consumers respond to corporate social initiatives. California Management Review, 47(1), 9-24. doi:10.2307/41166284

Bitner, M. J. (1992). Servicescapes: The impact of physical surroundings on customers and employees. Journal of Marketing, 56(2), 57-71. doi:10.1177/002224299205600205

Blau, P. (1964). Exchange and Power in Social Life. John Wiley and Sons.

Bolton, R. N., Lemon, K. N., \& Verhoef, P. C. (2004). The theoretical underpinnings of customer asset management: A framework and propositions for future research. Journal of the Academy of Marketing Science, 32(3), 271-292. doi:10.1177/0092070304263341

Bowen, J., \& Chen, S. (2001). The relationship between customer loyalty and customer satisfaction. International Journal of Contemporary Hospitality Management, 13(5), 213-217. doi:10.1108/09596110110395893 
Brown, T., \& Dacin, P. A. (1997). The company and the product: Corporate associations and consumer product responses. Journal of Marketing, 61(1), 68-84. doi:10.1177/002224299706100106

Broyles, S. A., Schumann, D. W., \& Leingpibul, T. (2009). Examining Brand Equity Antecedent/Consequence Relationships. Journal of Marketing Theory and Practice, 17(2), 145-162. doi:10.2753/MTP1069-6679170204

Carroll, A. B. (1979). A three-dimensional conceptual model of corporate performance. Academy of Management Review, 4(4), 497-505. doi:10.5465/amr.1979.4498296

Carroll, A. B. (1991). The pyramid of corporate social responsibility: Toward the moral management of organizational stakeholders. Business Horizons, 34(4), 39-48. doi:10.1016/0007-6813(91)90005-G

Central Administration of Statistics, and Center for Educational Research and Development. (2018). Students: Lebanee University. Retrieved from BRITE: https://brite.blominvestbank.com/series/Students-LebaneseUniversity-37726/

Chaudhuri, A., \& Holbrook, M. B. (2001). The Chain of Effects from Brand Trust and Brand Affect to Brand Performance: The Role of Brand Loyalty. Journal of Marketing, 65(2), 81-93. doi:10.1509/jmkg.65.2.81.18255

Chiou, J. S., \& Droge, C. (2006). Service quality, trust, specific asset investment, and expertise: Direct and indirect effects in a satisfaction-loyalty framework. Journal of the Academy of Marketing Science, 34(4), 613-627. doi: $10.1177 / 0092070306286934$

Cho, E., Lee, J., \& Lee, Y. (2017). Corporate Philanthropy Affecting Consumer Patronage Behavior: The Effect of Reciprocity and the Moderating Roles of Vicarious Licensing and Strategic Fit. Sustainability, 9(7), 1-15. doi:10.3390/su9071094

Choi, Y. G., Ok, C., \& Hyun, S. S. (2017). Relationships between brand experiences, personality traits, prestige, relationship quality, and loyalty. International Journal of Contemporary Hospitality Management, 29(4), 1185-1202. doi:10.1108/JJCHM-11-2014-0601

Choudhury, K. (2015). Evaluating customer-perceived service quality in business management education in India. Asia Pacific Journal of Marketing and Logistics, 27(2), 208-225. doi:10.1108/APJML-04-2014-0065

Correia Loureiro, S. M., \& Kaufmann, H. R. (2012). Explaining Love of Wine Brands. Journal of Promotion Management, 18(3), 329-343. doi:10.1080/10496491.2012.696460

Cuesta-Valiño, P., Rodríguez, P. G., \& Núñez-Barriopedro, E. (2019). The impact of corporate social responsibility on customer loyalty in hypermarkets: A new socially responsible strategy. Corporate Social Responsibility and Environmental Management, 26(4), 761-769. doi:10.1002/csr.1718

Dhabi, J. (2020). Lebanon's Double Crisis Crushes Both Students and Universities. Al-Fanar Media. https:// www.al-fanarmedia.org/2020/06/lebanons-double-crisis-crushes-both-students-and-universities/

Dick, A. S., \& Basu, K. (1994). Customer Loyalty: Toward an Integrated Conceptual Framework. Journal of the Academy of Marketing Science, 22(2), 99-113. doi:10.1177/0092070394222001

Easa, N., \& Bazzi, A. (2020). COVID-19 and lack of socialization: does service innovation become an imperative for universities? International Journal of Disruptive Innovation in Government, ahead of print.

Eisingerich, A. B., Rubera, G., Seifert, M., \& Bhardwaj, G. (2011). Doing good and doing better despite negative information? The role of corporate social responsibility in consumer resistance to negative information. Journal of Service Research, 14, 60-75.

Engizek, N., \& Yasin, B. (2017). How CSR and overall service quality lead to affective commitment: Mediating role of company reputation. Social Responsibility Journal, 13, 111-125.

Evanschitzky, H., \& Plassmann, H. (2006). The relative strength of affective commitment in securing loyalty in service relationships. Journal of Business Research, 59, 1207-1213.

Fatma, M., Khan, I., \& Rahman, Z. (2018). CSR and consumer behavioral responses: The role of customercompany identification. Asia Pacific Journal of Marketing and Logistics, 30(2), 460-477. doi:10.1108/ APJML-01-2017-0017 
Fatma, M., \& Rahman, Z. (2016). The CSR's influence on customer responses in Indian banking sector. Journal of Retailing and Consumer Services, 29, 49-57. doi:10.1016/j.jretconser.2015.11.008

Guadagni, P. M., \& Little, J. D. C. (2008). A Logit Model of Brand Choice Calibrated on Scanner Data. Marketing Science, 27(1), 29-48.

Gürlek, M., Düzgün, E., \& Uygur, S. (2017). How does corporate social responsibility create customer loyalty? The role of corporate image. Social Responsibility Journal, 13(3), 409-427.

Han, H., Yu, J., Lee, J.-S., \& Kim, W. (2019). Impact of hotels' sustainability practices on guest attitudinal loyalty: Application of loyalty chain stages theory. Journal of Hospitality Marketing \& Management, 28(8), 905-925.

He, Y., \& Lai, K. K. (2012). The effect of corporate social responsibility on brand loyalty: The mediating role of brand image. Total Quality Management \& Business Excellence, 25(3-4), 249-263.

Hejase, H., Cybelle, F., Haddad, Z., \& Hamdar, B. (2012). Exploring the Multiple Benefits of CSR on Organizational Performance: Case of Lebanon. Journal of Social Sciences. COES\&R-JSS, 1(1), 1-23.

Helgesen, O., \& Nesset, E. (2007). What accounts for students' loyalty? Some field study evidence. International Journal of Educational Management, 21(2), 126-143.

Hennig-Thurau, T., Langer, M. F., \& Hansen, U. (2001). Modeling and Managing Student Loyalty. Journal of Service Research, 3(4), 331-344.

Howes, M., Wortley, L., Potts, R., \& Dedekorkut-Howes, A., SerraoNeumann, S., Davidson, J., \& Nunn, P. (2017). Environmental sustainability: A case of policy implementation failure? Sustainability, 9(2), 165.

Iglesias, O., Markovic, S., Bagherzadeh, M., \& Singh, J. J. (2018). Co-creation: A key link between corporate social responsibility, customer trust, and customer loyalty. Journal of Business Ethics, 163, 151-166.

Issam Fares Institute for Public Policy and International Affairs. (2020). Open Dialogue on Lebanon's Education. https://www.aub.edu.lb/ifi/Documents/programs/education_and_youth_policy/documents/20200228_open_ dialogue_on_education_sector_lebanon/20200228_open_dialogue_on_education_sector_lebanon.pdfaub.edu.lb

Jacoby, J., \& Chestnut, R. (1978). Brand loyalty: measurement and management. John Wiley and Sons.

Jacoby, J., \& Kyner, D. B. (1973). Brand loyalty vs. repeat purchasing behavior. JMR, Journal of Marketing Research, 10(1), 1-10.

Kang, J.-W., \& Namkung, Y. (2017). The Effect of Corporate Social Responsibility on Brand Equity and the Moderating Role of Ethical Consumerism: The Case of Starbucks. Journal of Hospitality \& Tourism Research (Washington, D.C.), 42(7), 1130-1151.

Karunaratna, A. C., \& Kumara, P. A. P. S. (2018). Determinants of customer loyalty: A literature review. Journal of Customer Behaviour, 17(1), 49-73.

Khawja, L., Abbass Ali, A., \& Mostapha, N. (2020). The mediating effect of customer satisfaction in relationship with service quality, corporate social responsibility, perceived quality and brand loyalty. Management Science Letters, 11(3), 763-772.

Kilburn, B., Kilburn, A., \& Davis D. (2016). Building Collegiate E-loyalty: the role of perceived value in the quality-loyalty linkage in online higher education. Contemporary Issues in Education Research, 9(3), 95-102.

Kim, E., \& Ham, S. (2016). Restaurants' disclosure of nutritional information as a corporate social responsibility initiative: Customers' attitudinal and behavioral responses. International Journal of Hospitality Management, 55, 96-106.

Kotler, P., \& Armstrong, G. (2008). Principles of marketing (12th ed.). Prentice-Hall.

Lacey, R., Kennett-Hensel, P. A., \& Manolis, C. (2015). Is corporate social responsibility a motivator or hygiene factor? Insights into its bivalent nature. Journal of the Academy of Marketing Science, 43(3), 315-332.

Lee, S., Han, H., Radic, A., \& Tariq, B. (2020). Corporate social responsibility (CSR) as a customer satisfaction and retention strategy in the chain restaurant sector. Journal of Hospitality and Tourism Management, 45, 348-358. 
Lewis, B. R., \& Soureli, M. (2006). The antecedents of consumer loyalty in retail banking. Journal of Consumer Behaviour, 5(1), 15-31.

Lichtenstein, D. R., Drumwright, M. E., \& Braig, B. M. (2004). The effect of corporate social responsibility on customer donations to corporate-supported nonprofits. Journal of Marketing, 68, 16-32.

Liu, M. T., Liu, Y., Mo, Z., Zhao, Z., \& Zhu, Z. (2019). How CSR influences customer behavioural loyalty in the Chinese hotel industry. Asia Pacific Journal of Marketing and Logistics, 32(1), 1-22.

Lu, X., Liu, H. W., \& Rahman, M. (2017). The impact of corporate social responsibility on customer loyalty: A case for two global corporations in China. Strategic Change, 26(3), 251-260.

Luu, T. T. (2017). CSR and organizational citizenship behavior for the environment in hotel industry. International Journal of Contemporary Hospitality Management, 29(11), 2867-2900.

Maignan, I., \& Ferrell, O. C. (2001). Corporate citizen as a marketing instrument - concepts, evidence and research directions. European Journal of Marketing, 35(3/4), 457-484.

Mandhachitara, R., \& Poolthong, Y. (2011). A model of customer loyalty and corporate social responsibility. Journal of Services Marketing, 25, 122-133.

Marin, L., Ruiz, S., \& Rubio, A. (2009). The role of identity salience in the effects of corporate social responsibility on consumer behavior. Journal of Business Ethics, 84(1), 65-78.

Martínez, P., \& Rodríguez del Bosque, I. (2013). CSR and customer loyalty: The roles of trust, customer identification with the company and satisfaction. International Journal of Hospitality Management, 35, 89-99.

McWilliams, A., \& Siegel, D. (2001). Corporate social responsibility: A Theory of the Firm Perspective. Academy of Management Review, 26(1), 117-127.

Miles, A. J. (2012). Management and Organization Theory. Jossey-Bass.

Moogan, Y. J. (2011). Can a higher education institution's marketing strategy improve the student-institution match? International Journal of Educational Management, 25(6), 570-589.

Mostafa, R. (2019). Does social media website really matter in enhancing student's retention intention? An application of Stimulus-Organism-Response framework. International Journal of Management Education, 13(4), 397-416.

Newman, J. W., \& Werbel, R. A. (1973). Multivariate Analysis of brand loyalty for major household appliances. JMR, Journal of Marketing Research, 10(4), 404-409.

Nikabadi, M. S., Safui, M. A., \& Agheshlouei, H. (2015). Role of Advertising and Promotion in Brand Equity Creation. Journal of Promotion Management, 21(1), 13-32.

Nyadzayo, M. W., \& Khajehzadeh, S. (2016). The antecedents of customer loyalty: A moderated mediation model of customer relationship management quality and brand image. Journal of Retailing and Consumer Services, 30, 262-270.

O'Cass, A., \& Sok, P. (2015). An exploratory study into managing value creation in tourism service firms: Understanding value creation phases at the intersection of the tourism service firm and their customers. Tourism Management, 51, 186-200.

Oliver, R. L. (1999). Whence consumer loyalty? Journal of Marketing, 63(4), 33-44.

Onlaor, W., \& Rotchanakitumnuai, S. (2010). Enhancing Customer Loyalty towards Corporate Social Responsibility of Thai Mobile Service Providers. World Academy of Science, Engineering and Technology, $42,1560-1564$.

Oppermann, M. (2000). Tourism destination loyalty. Journal of Travel Research, 39(1), 78-84.

Pham, L., Williamson, S., \& Berry, R. (2018). Student Perceptions of E-Learning Service Quality, E-Satisfaction, and E-Loyalty. International Journal of Enterprise Information Systems, 14(3), 19-40.

Pivato, S., Misani, N., \& Tencati, A. (2008). The impact of corporate social responsibility on consumer trust: The case of organic food. Business Ethics (Oxford, England), 17(1), 3-12. 
Raza, A., Rather, R. A., Iqbal, M. K., \& Bhutta, U. S. (2020). An assessment of corporate social responsibility on customer company identification and loyalty in banking industry: a PLS-SEM analysis. Management Research Review.

Raza, A., Saeed, A., Iqbal, M. K., Saeed, U., Sadiq, I., \& Faraz, N. A. (2020). Linking Corporate Social Responsibility to Customer Loyalty through Co-Creation and Customer Company Identification: Exploring Sequential Mediation Mechanism. Sustainability, 12(6), 2525.

Salmones, G. 1., Crespo, A. H., \& Bosque, I. R. d. (2005). Influence of Corporate Social Responsibility on loyalty and valuation of services. Journal of Business Ethics, 61, 369-385.

Servera-Francés, D., \& Piqueras-Tomás, L. (2019). The effects of corporate social responsibility on consumer loyalty through consumer perceived value. Economic Research-Ekonomska Istraživanja, 32(1), 66-84.

Shabbir, M., Shariff, M., Bin Yusof, M., Salman, R., \& Hafeez, S. (2018). Corporate social responsibility and customer loyalty in Islamic banks of Pakistan: A mediating role of brand image. Academy of Accounting and Financial Studies Journal, 22, 1-19.

Shin, Y., \& Thai, V. V. (2014). The Impact of Corporate Social Responsibility on Customer Satisfaction, Relationship Maintenance and Loyalty in the Shipping Industry. Corporate Social Responsibility and Environmental Management, 22(6), 381-392.

Singh, J., de los Salmones Sanchez, M., \& Del Bosque, I. (2008). Understanding Corporate Social Responsibility and Product Perceptions in Consumer Markets: A Cross-cultural Evaluation. Journal of Business Ethics, 80(3), 597-611.

Sirdeshmukh, D., Singh, J., \& Sabol, B. (2002). Consumer Trust, Value, and Loyalty in Relational Exchanges. Journal of Marketing, 66(1), 15-37.

Tajfel, H., \& Trurner, J. C. (1986). The social identity theory of intergroup behavior. In S. Worchel \& W. G. Austin (Eds.), Psychology of Intergroup relations (pp. 7-24). Nelsoo-Hall.

Tellis, G. J. (1988). Advertising Exposure, Loyalty, and Brand Purchase: A Two-Stage Model of Choice. JMR, Journal of Marketing Research, 25(2), 134-144.

Vianden, J., \& Barlow, P. J. (2014). Showing the Love: Predictors of Student Loyalty to Undergraduate Institutions. Journal of Student Affairs Research and Practice, 51(1), 16-29.

Vlachos, P. A., Tsamakos, A., Vrechopoulos, A. P., \& Avramidis, P. K. (2009). Corporate social responsibility: Attributions, loyalty, and the mediating role of trust. Journal of the Academy of Marketing Science, 37(2), 170-180.

Walsh, G., \& Bartikowski, B. (2013). Exploring corporate ability and social responsibility associations as antecedents of customer satisfaction cross-culturally. Journal of Business Research, 66(8), 989-995.

Wang, Q., Dou, J., \& Jia, S. (2016). A Meta-Analytic Review of Corporate Social Responsibility and Corporate Financial Performance. Business \& Society, 55(8), 1083-1121.

Werther, W. B. Jr, \& Chandler, D. (2005). Strategic corporate social responsibility as global brand insurance. Business Horizons, 48(4), 317-324.

Worthington, S., Russell-Bennett, R., \& Härtel, C. (2010). A tri-dimensional approach for auditing brand loyalty. Journal of Brand Management, 17(4), 243-253.

Wright, T. (2010). University presidents' conceptualizations of sustainability in higher education. International Journal of Sustainability in Higher Education, 11(1), 61-73.

Zeithaml, V. A., Berry, L. L., Parasuraman, A., Beatty, S., Chen, X., \& Schultz, F. (1996). The Behavioral consequences of service quality. Journal of Marketing, 60(2), 31-46. 


\section{APPENDIX A. QUESTIONNAIRE ITEMS}

\begin{tabular}{|c|c|}
\hline Customer Loyalty & \\
\hline \multirow[t]{4}{*}{ Attitudinal loyalty } & You will say positive things about your university \\
\hline & You will always consider your university as your first choice \\
\hline & You consider yourself to be a loyal supporter to your university \\
\hline & You will recommend your university to others \\
\hline \multirow[t]{3}{*}{ Behavioral Loyalty } & You will definitely keep using this university \\
\hline & You will use this university the next time you need to accomplish new study \\
\hline & You will do most of your study in this university \\
\hline \multicolumn{2}{|l|}{$\begin{array}{l}\text { Corporate Social } \\
\text { Responsibility }\end{array}$} \\
\hline \multirow[t]{3}{*}{ Economic responsibility } & Your university tries to obtain maximum profit from its activity \\
\hline & Your university tries to obtain maximum long-term success \\
\hline & Your university always tries to improve its economic performance \\
\hline \multirow[t]{4}{*}{ Ethical-legal responsibility } & $\begin{array}{l}\text { Your university always respects the norms defined in the law when carrying out its } \\
\text { activities. }\end{array}$ \\
\hline & $\begin{array}{l}\text { Your university is concerned to fulfill its obligations toward its shareholders, } \\
\text { suppliers, distributions, and other agents with whom it deals. }\end{array}$ \\
\hline & Your university behaves ethically/honestly with its students. \\
\hline & $\begin{array}{l}\text { Your university is respecting ethical principles in its relationships has priority } \\
\text { overachieving superior economic performance. }\end{array}$ \\
\hline \multirow[t]{4}{*}{ Philanthropic responsibility } & Your university is considered in respecting and protecting natural environment. \\
\hline & $\begin{array}{l}\text { Your university is actively sponsoring and or financing social events (sport, } \\
\text { music,...). }\end{array}$ \\
\hline & $\begin{array}{l}\text { Your university directs a part of its budget to donations and social works favoring the } \\
\text { disadvantaged. }\end{array}$ \\
\hline & Your university is concerned to improve general well-being of society. \\
\hline
\end{tabular}

Rania B. Mostafa is an Associate Professor in Marketing at Al Ain University, UAE and Faculty of Commerce, Damanhour University, Egypt. Rania holds a PhD in Marketing from the University of Leeds (UK). Her research interests focus on service marketing and service recovery, technology acceptance model, social media, and value co-creation. Rania has published several research articles in relevant journals including Journal of Service Research, Journal of Services Marketing, Journal of Marketing Education, Organizations and Markets in Emerging Economies, Journal of Research in Interactive Marketing, International Journal of Bank Marketing, Journal of Promotion Management, and Journal of Strategic Marketing, among others.

Leila Hamieh is a PhD student in Beirut Arab University. Her area of interests includes Marketing Strategy and Consumer Behavior. 